\title{
Transitivity of English Verbs in Short Story "Pinnochio"
}

\author{
Putu Ayu Sada Devi Pradnyadari \\ English Department, Faculty of Arts, Udayana University \\ [ayu.sada@yahoo.com]
}

\begin{abstract}
This undergraduate thesis examines the type of transitive verbs found in a children story entitled "Pinocchio", which was taken from the children story book entitled Disney Storyland Treasury, and analyzes the degree of transitivity found in the story. The data were collected using the documentation method and were analyzed using the descriptive qualitative method. In addition, in order to present the data analysis clearly, both formal and informal methods were used since the data were described in form of sentences and tables. The main theory applied in this study is proposed by Hopper and Thompson (1980) about transitivity, who said that transitivity is a matter of degree and partly because obviousness of change in the object. This theory is supported by the types of verb proposed by Givon (1984), which is used to find out the types of verb in the story. The finding of the analysis showed that there were three types of verbs found in the story namely state verb, action verb and process verb. Each verb has different degree of transitivity, where the degree of state verb is categorized as low in transitivity, action and process verbs have the highest degree of parameter of transitivity.
\end{abstract}

Keywords: transitivity, verb, children story, degree of parameters

\begin{abstract}
Abstrak
Penelitian ini mengkaji tipe dan menganalisis derajat ketransitifan dari kata kerja transitif yang ditemukan di cerita anak berjudul "Pinocchio", yang terdapat di dalam buku cerita anak berjudul "Disney Storyland Treasury". Data dalam penelitian ini diperoleh dengan menggunakan metode dokumentasi dan dianalis dengan metode kualitatif. Sebagai tambahan, analisis dalam penelitian ini menggunakan metode formal dan informal sebab data akan dijelaskan dalam bentuk kalimat dan tabel. Teori utama dalam penelitian ini dikemukakan oleh Hopper dan Thompson (1980) tentang ketransitifan, yang mengatakan bahwa ketransitifan adalah persoalan derajat dan sebagian karena kejelasan dari perubahan suatu objek. Teori ini didukung oleh teori mengenai tipe kata kerja yang dikemukakan oleh Givon (1984), yang digunakan untuk mengetahui tipe kata kerja yang terdapat dalam cerita. Berdasarkan analisis yang telah dikakukan, ditemukan ada tiga tipe kata kerja sesuai dengan teori dari Givon, yaitu kata kerja pernyataan, kata kerja aksi, dan kata kerja proses. Setiap kata kerja memiliki derajat ketransitifan yang berbeda, dimana kata kerja pernyataan digolongkan sebagai kata kerja yang rendah dalam ketransitifan. Untuk kata kerja aksi dan proses memperoleh derajat tertinggi atau dapat dinyatakan sebagai tinggi dalam ketransitifan.
\end{abstract}

Kata kunci: ketransitifan, kata kerja, cerita anak, derajat parameter 


\section{Background of the Study}

English as a foreign language in Indonesia becomes the most wanted language to be tought to children at young age. Most parents will teach their children by reading stories or letting them read the story by themselves, because most stories contain the use of language that are considered to be in the language use in communication. Stories are frequently claimed to bring many benefits to young learners, including language development (Wright 1997; Garvie 1990).

The choice of words used in the story book should be different from the words used by the adult. This study used the theory of transitivity proposed by Hopper \& Thompson (1980: 251-299), which combined the verb with other words, people can form sentences to convey meaning. In linguistics, the study of meaning is called semantics. In semantics, it is known that verb has degree of transitivity. The degree of transitivity can be analyzed using parameter of transitivity.

From the explanation above, the transitivity process is really interesting to be analyzed by applying the theory proposed by Givon (1984) in identifying the type of English verb found in the children's story, using theory proposed by Hopper and Thompson (1980) in finding out the degree of transitivity of those verbs. Besides, the concept of transitivity in Hopper and Thompson's parameter is a powerful tool for analyzing the collected data. Through this research, we can learn deeper about the types of transitive verb and how to find out the lowest and highest parameters of transitivity of the verbs.

There are so many previous studies that have analyzed transitivity of English verbs. The chosen story to be analyzed in this study is entitled Pinocchio, which is taken from Disney Storyland Treasury for children, because this children story has lots of verbs inside, which means that there are lots of verb types and degree contained in each sentence. Thus, this study is different from the other studies, because it is concerned with the type and the degree of verb transitivity found in children story as it means to get the real meaning from the verb itself. This study also uses the theory proposed by Givon (1984) to identify the type of English verb found in the children story and using theory proposed by Hopper and Thompson (1980) to find out the degree of transitivity of those verbs.

\section{Problems of the Study}

a) What types of transitive verbs are found in the children story entitled Pinocchio taken from Disney Storyland Treasury?

b) What is the degree of transitivity of verbs found in the children story entitled Pinocchio taken from Disney Storyland Treasury?

\section{Aims of Study}

a) To identify the types of transitive verbs found in the children story entitled Pinocchio taken from Disney Storyland Treasury.

b) To find out the degree of verbs transitivity found in the children story entitled Pinocchio taken from Disney Storyland Treasury.

\section{Research Method}

In writing an academic study, it is necessary to follow a systematic procedure on how certain research could be conducted. In this context, the research method is required in order to determine the appropriate procedures of the study which mainly consists of three aspects, namely (1) Data Source; (2) Method and Technique of Collecting Data; (3) Method and Technique of Analyzing Data; and (4) Method and Technique of Presenting Data. 


\subsection{Data Source}

The data source used for this study was taken from one of the most popular children's book entitled Disney Storyland Treasury (2013). Originally, this book was published in1950s which was illustrated by the celebration of Walt Disney Studio artist.

The data source was taken from the story of Pinocchio, since this story was put on the first chapter of the book. This story also has more verbs used inside, which are available to be analyzed such as state, process, and action verbs. In addition, the degree of transitivity of those verbs can be analyzed using the parameter of transitivity which is the focus of this study. This made Pinocchio the most appropriate data to be analyzed.

\subsection{Method and Technique of Collecting Data}

The data were collected through some steps. This study is a library research; therefore, documentation methods were applied and the data were collected through some steps. After the data source was found by searching some of the famous children stories and chose the story randomly, the second step was continued by reading the story to identify the verbs in the story with skimming technique. Reading the sentence or clauses from the stories was done in order to choose the verbs and the appropriate verbs which were relevant with the scope of discussion in this study. After the data were chosen, taking note was used to find whenever the sentence contains the transitivity of verb. These steps were used to find the accurate data in the story entitled Pinocchio.

\subsection{Method and Technique of Analyzing Data}

The collected data in this study were analyzed using the qualitative method. So far the qualitative method is the most ideal one used to analyze this type of library reserach study. There are some steps in analyzing the collected data. First, the collected data were analyzed using the theory proposed by Givon (1984). Second, classifying the verb into three types of verb according to the theory proposed by Givon (1984). After that, the index parameter of each verb in the collected data was counted in order to find out the degree of verb transitivity based on Hopper and Thompson theory (1980).

\subsection{Method and Technique of Presenting Data}

In presenting the data, formal and informal method were used, since the data were explained and described in the form of tables and sentences through several steps as follows; firstly, the collected data were analyzed and classified into three types of verbs according to the theory proposed by Givon (1984). Second, each parameter of the collected verbs was explained descriptively. The next step, the index parameter of the verb found as the data was counted in order to find out the degree of verb transitivity in the form of table based on the theory proposed by Hopper and Thompson (1980).

\section{Result and Discussion}

\subsection{Types of Transitive Verb in Pinocchio Story}

\subsubsection{State Verb}

In this section, only a brief explanation of the meaning of the state verb is discussed, for the parameter and the index exist in the sentences are explained in the other sections. According to Givon (1984: 87), state verb is used to state the condition of the agent and the patient in the sentence. In the children story entitled "Pinocchio", there are several state verbs that are used in making sentences. One of those data are shown and explained below. 
(5-1) Pinocchio saw the sea creatures fleeing. (Pg. 134)

The verb saw is the past form of the verb see. In sentence 1 , the verb is considered the state verb. This is consistent with the definition according to Givon stating that state verb is the verb that cannot change a state or condition of object. The meaning of this sentence is that the agent Pinocchio knows what object the sea creatures is doing, meaning that the agent only knows something happening with the object. The verb saw which is done by the agent does not change the state or condition on the object.

\subsubsection{Action Verb}

This section gives brief explanation of the meaning that exists in the action verb being discussed. The parameter and the index exist in the sentences are explained in the other sub chapter. Action verb is a verb that can make something happen to the patient or represent a transferred action from an agent to a patient (Givon, 1984: 89). In the data source, a children story entitled "Pinocchio", there are several action verbs used in making sentences. One of those data are shown and explained below.

(5-2) Pinocchio ran to him and threw his wooden arms around his neck. (Pg. 117)

Sentence 2 is the form of complex sentences made by two sentences that have the same agent occurring at the same point. The sentences are combined with the help of the conjunction and. Furthermore, there are two verbs existing in the sentence. There are ran and threw. The sentences can be elaborated below:

a. Pinocchio ran to him.

b. Pinocchio threw his wooden arms around his neck.

However, only threw in sentence (b) is considered the transitive verb based on the theory proposed by Givon (1984). The other verb belongs to the intransitive verb that only needs one participant attached to the verb. Therefore, the only verb threw is explained in this sub chapter. The verb threw is the past form of the verb throw. This verb is considered the action verb since the agent does something to the patient. The action is done to make something happen to the patient in the sentence. In this sentence, the patient experiences something done by the agent. It represents a transferred action done by the agent to the patient. In sentence 4, the agent Pinocchio does something to the patient his wooden arms. The patient affects the result taken by the agent because the action makes it move or change position.

\subsubsection{Process Verb}

This section discusses the meaning of the action verb. For the parameters and the index exsisting in the sentences are explained in the other sub chapter. Process verb is a verb which is characterized by the verb that denotes a much slower process of change (Givon, 1984: 90). In the children story entitled "Pinocchio", there are several action verbs used to make sentences. One of those data is shown and explained below.

(5-3) Suddenly, he drew his breath and gave a monstrous sneeze. (Pg. 136)

In sentence 3 , there are two transitive verbs. The sentence is collaborated with conjunction 'and'. A conjunction is an action or an instance of two or more events or things occurring at the same point in time or space, it is also said that conjunction is also a word used to connect clauses or sentences or to coordinate words in the same clause (Oxford Dictionary, 2010: 306). This sentence can be elaborated as:

c. He drew his breath.

d. He gave a monstrous sneeze.

The first one in sentence (c), there is verb drew is the past form of verb 
draw. This verb is categorized as process verb. This verb shows that there is a process of agent doing something to the patient. It donates a slower action of change to the patient. In this sentence, the agent he does a process to make something done for the patient his breath. The action gives the explanation of how the process of something to happen to the patient in the sentence. The patient experiences something done by the agent however with a slower process. The agent does the process of making something experienced by the patient. It also has the meaning of gathering process to make something in the end that effects the patient.

\subsection{The Degree of Transitivity of Verbs in Pinocchio Story}

\subsubsection{The Parameter of Transitivity of} State Verb

The parameter of transitivity of state verb is taken from the example of the chosen data found in the children story entitled "Pinocchio".

(5-1) Pinocchio saw the sea creatures fleeing. (Pg. 134)

The verb saw in sentence 1, which is the past form of the verb see, has one participant which is Pinocchio. There is no patient in this sentence. The object the sea creatures fleeing acts as a theme. Theme in semantics means undergoing the action but does not change its state. In term of kinesis, the verb saw cannot change the condition of patient, since the agent only knows what the patient does without doing something to the patient. Therefore, it belongs to the non-action verb. This verb is telic since the action is already finished. The verb is also categorized as realis because it has already occurred in the sentence. It is punctual because saw is done without any duration. The verb saw is not volitional because there is no purpose in the sentence. It is shown by the agent Pinocchio who unconditionally knows what the patient the sea creatures do in the sentence. It means that the agent does not intend to do the state of the verb just to know about what the patient does. The verb saw is affirmative, since the verb is in the positive form. In term of agency, the agent is low in potency because the agent does not transfer any action to the patient. The object of the sentence is not affected by what the agent does. Furthermore, the object is not individuated. It can be proved by the suffix $-S$ in the end of the noun phrase. Thus, in the English grammatical term, this suffix functions to change the form of a noun from singular into plural. It means that the patient is non-individuated in the sentence since the patient is plural.

\section{The Parameter of Verb Saw}

\begin{tabular}{llc}
\hline Parameters & $\begin{array}{l}\text { The Verb } \\
\text { Saw }\end{array}$ & Index \\
\hline A. Participant & $\begin{array}{l}\text { One } \\
\text { participant }\end{array}$ & 0 \\
& Non-Action & 0 \\
B. Kinesis & Telic & 1 \\
C. Aspect & Punctual & 1 \\
D. Punctuality & Non- & 0 \\
E. Volitionality & Nolitional & 1 \\
F. Affirmation & Volitive & 1 \\
G. Mode & Affirmative & 0 \\
H. Agency & Realis & \\
& A low in & \\
I. Affectedness & O notency totally & 0 \\
$\quad$ of O & affected & \\
J. Individuation & O non- & 0 \\
$\quad$ of O & individuated & \\
Total & & 4 \\
\hline
\end{tabular}

From the table above, it can be seen that the verb saw in sentence 1 is categorized in low parameter of transitivity because the value is four. This is as stated in the parameter of indexation stated by Hopper and Thomson (1980: $525)$.

\subsubsection{The Parameter of Transitivity of Action Verb \\ The parameter of transitivity of} action verb is taken from the example of 
the chosen data found in the children story entitled "Pinocchio".

(5-2) Pinocchio ran to him and threw his wooden arms around his neck. (Pg. 117)

Since this sentence is a complex sentence formed by two sentences with the conjuction and, thus the elaboration of the sentences are:

a. Pinocchio ran to him.

b. Pinocchio threw his wooden arms around his neck.

The only the verb in sentence (b) that is categorized as transitive, while sentence (a) is intransitive verb. The verb threw in sentence 2, which is the past form of the verb throw belongs to the transitive verb because it has two participants Pinocchio and his wooden arms. In term of kinesis, the verb throw has direct physical activity to the patient, thus the patient receives something from the agent. Therefore, it belongs to the action verb. This verb is telic since the action is already finished. The verb is also categorized as realis because it has already occurred in the sentence and it is already done by the agent. It is punctual because threw is done without any duration. The verb threw is categorized as volitional because the agent has the purpose to do the verb to the patient. The agent Pinocchio has the intention to do the action to express its feeling to the patient and hopes that the patient feels something. The effect on the patient is typically more apparent when the agent is presented as acting purposefully. The verb threw is affirmative, since the verb is included in the positive form. In terms of agency, the agent has a high potency because the agent is animate. The object of the sentence is affected by what the agent does because the action is being transferred to the patient. It makes the patient feel something because of the action. Furthermore, the object is highly individuated. It can be proved by the possessive determiner his in the sentence which belongs to the possession of the agent.

The Parameter of Verb Threw

\begin{tabular}{llc}
\hline Parameters & $\begin{array}{l}\text { The Verb } \\
\text { Threw }\end{array}$ & Index \\
\hline A. Participant & $\begin{array}{l}\text { Two } \\
\text { participants }\end{array}$ & 1 \\
B. Kinesis & Action & 1 \\
C. Aspect & Telic & 1 \\
D. Punctuality & Punctual & 1 \\
E. Volitionality & Volitional & 1 \\
F. Affirmation & Affirmative & 1 \\
$\begin{array}{l}\text { G. Mode } \\
\text { H. Agency }\end{array}$ & $\begin{array}{l}\text { Realis } \\
\text { A high in }\end{array}$ & 1 \\
I. Affectedness & O O is affected & 1 \\
J. Individuation & O is & 1 \\
$\quad$ of O & individuated & \\
Total & & 10 \\
\hline
\end{tabular}

From the table above, it can be seen that the verb threw in sentence 2 has the highest parameters of transitivity because the value is full, which is ten. This is as stated in the parameter of indexation stated by Hopper and Thomson (1980: 525).

\subsubsection{The Parameter of Transitivity of Process Verb}

The parameter of transitivity of process verb is taken from the example of the chosen data found in the children story entitled "Pinocchio". The elaboration of parameter of the verbs is given below.

(5-3) Suddenly, he drew his breath and gave a monstrous sneeze. (Pg. 136)

Sentence 3 is categorized as complex sentence. It consists of two sentences collaborated into one by the conjunction and. The sentence can be elaborated as:

c. He drew his breath.

d. He gave a monstrous sneeze.

The two verbs in sentence (c) and (d) are categorized as transitive verb; however, the only verb in sentence (c) that is categorized in the process verb. 
Therefore, the explanation of the parameter of transitivity of action verb only explains the verb in sentence (d). The verb drew in sentence (c), which is the past form of the verb draw, belongs to the transitive verb because it has two participants he and his breath. In term of kinesis, the verb drew changes the condition of patient; however, the action has the process of changing it. It means that the verb does not do instantly; however, there is a process in the verb. This action has direct physical activity done by the agent to the patient. Therefore, the verb belongs to the process verb. This verb is telic since the action is already finished. It can be seen from the past form of the verb, which explains the action happening in the past and it is already done. The verb is also categorized as realis because it has already occurred in the sentence. It is punctual because drew is done without any duration. The verb drew is categorized as volitional because the agent has the purpose to do something to the patient in the sentence. The agent he intentionally does something to patient his breath in order to inhale the patient because the patient is inanimate, air. The movement has the process to change the location of the patient done by the agent. Therefore, it is categorized as volitional. The verb drew is affirmative, because the verb is included in the positive form. In terms of agency, the agent is high in potency because the agent is animate. The object of the sentence is affected by what the agent does, because there is a direct physical action which makes the patient experience what the agent does and gets inside the agent's body. Furthermore, the object is highly individuated. It can be proved by the possessive pronoun his that refers to a specific object that the agent possesses.

\section{The Parameter of Verb Drew}

\begin{tabular}{lll}
\hline Parameters & $\begin{array}{l}\text { The Verb } \\
\text { Drew }\end{array}$ & Index \\
\hline A. Participant & $\begin{array}{l}\text { Two } \\
\text { participants }\end{array}$ & 1 \\
B. Kinesis & Action & 1 \\
C. Aspect & Telic & 1 \\
D. Punctuality & Punctual & 1 \\
E. Volitionality & Volitional & 1 \\
F. Affirmation & Affirmative & 1 \\
G. Mode & Realis & 1 \\
H. Agency & A high in & 1 \\
potency & \\
I. Affectedness & O is affected & 1 \\
\multicolumn{1}{l}{ of O } & O is & 1 \\
J. Individuation & individuated & \\
Total O & & \\
\hline
\end{tabular}

From the table above, it can be seen that the verb drew in sentence 3 is another the highest parameter of transitivity because the value is the maximum ten. This is as stated in the parameter of indexation stated by Hopper and Thomson (1980: 525).

\section{Conclusion}

Based on the findings presented previously, the three types of verb categories were all found here. Those verb categories are state verbs with 22 data, action verb with 26 data and process verb with 26 data. The total types of verb found in the data source are 74 data.

In relation to transitivity verbs, the degree of transitivity found in the story entitled Pinocchio are different in each type of verb. The degree of transitivity in the type of state verbs are categorized as low in transitivity. The degree of transitivity in the type of action verbs are categorized as high in transitivity. The degree of transitivity in the type of process verbs are categorized as high in transitivity. Furthermore, the degree of transitivity of this book is high in 
transitivity since this book is highly dominated by action verb and process verb.

The result of the analysis of the study indicates that Givon's theory about classes of verbs and Hopper and Thompson's theory about the degree of transitivity can mostly be applied in the data. This study, nevertheless, is still preliminary. More comprehensive study needs further testing by looking at more data from different texts to have a more definite results regarding the transitivity of verbs.

\section{Bibliography}

Dixon, R.M.W. 1991. A New Approach to English Grammar, On Semantic Principles. Oxford University Press. Oxford.

Garvie, E., 1990. Story as vehicle. Clevedon, Avon: Multilingual Matters.

Givon. T. 1984. Syntax: A Functional Typological Introduction Volume I \& II. Amsterdam/Philadelphia: John Benjamins Publishing Company.

Hopper, P.J and Sandra A Thompson. 1980. Transitivity In Grammar and Discourse: Language, 56, 251-299 